\title{
The continued importance of Jesus
}

Andries van Aarde

Department of New Testament Studies (Sec A)

University of Pretoria

\begin{abstract}
The different aspects of the influential nature of Jesus' life were handed down only after his death by those who met God on the basis of the traditions with regard to Jesus. The historical Jesus is therefore to be distinguished from the kerygmatic Christ. This article aims at arguing that Jesus' call upon God as 'Abba' can be regarded as a dialectic material link between the historical Jesus and the kerygmatic Christ. It is also shown that this dialectic has divergently been articulated in the New Testament writings and thereafter as time has changed. Today the historical Jesus' message of the all-inclusiveness and already-presence of God's domain is to be taken seriously by the church in pursuing the kerygma in the New Testament. However, the category 'kerygmatic Christ' seems to be increasingly loosing its explanatory and heuristic power in the secular and postmodern religious age.
\end{abstract}

\section{WHAT IS THE ISSUE?}

The name Jesus occurs regularly among Israelites who were, around the beginning of the common era, influenced by Greek idiom. The historian Josephus (cf Whiston 1978:767) mentions at least twelve other Jesuses, apart from him 'who is called the Christ', and Joshua, the sun of Nun, of whom we read in the Old Testament, who played a part in the history of Israel during the Hellenistic period. The vast majority of these persons belonged to priestly and governing families 1 . However, when people today hear the word 'Jesus', or use it themselves, they probably have in mind that Jesus to whom Christians pray as if they are praying to God. For these people there is also no difference between the names 'Jesus' and 'Christ'. In other words, whether Christians use the names 'Jesus' or 'Christ' they always use it as if it refers to Jesus as God. This equation appears in words used long ago, at the end of the second century $\mathrm{CE}$, by Clement, a church father of Alexandria ${ }^{2}$. Similarly, the second-century church father of Antioch, Ignatius, refers to Christ as God as if such a statement were quite self-evident (see Ign Trall 7:1; Ign Smy 1:1; 10:1). Mostly, Ignatius ${ }^{3}$ used the

* A reworked version of a paper presented at the Images of Jesus Seminar, Research Institute for Theology and Religion, University of South Africa, September 3-4, 1997. 
expression: '(Jesus Christ) our Lord'. The New Testament, however, has in most instances reservations about calling Christ 'God'4. Furthermore, calling Jesus the Christ, on the basis of the New Testament, is not altogether obvious. As Den Heyer (1996:78-80) puts it, it is a matter of a Messiah who did not want to be a Messiah ('Een Messias wat geen Messias wilde zijn')!

People who know something about the origins of Christianity, accordingly, know that there is a difference between the Jesus of history and the Jesus of faith. The word 'faith' is, in this regard, a word which belongs in the ambit of the church, the believing community of Christians. Faith is experienced, lived, confessed and proclaimed in the church. All these events indicate that, to Christians, Jesus is more than merely a historical figure. The word 'than' is here an indication of the 'more' of which there is reference. Just as is the case with any other human, Jesus is in a sense elevated above history when he is viewed as somebody. Since before fifty years into the common era, and for almost two thousand years, Jesus has been proclaimed and confessed by Christians in the church as the Messiah of Israel, as Lord of the world, as the Child of God, as God himself - equal in being with the Father (since the fourth century) and with the Spirit (since the eighth century, and formulated in a specific way in the Western church since the beginning of the eleventh century). This Jesus is the 'Jesus of faith' in contradistinction to, yet irrevocably bound with, the 'Jesus of history'.

Different expressions are used to refer respectively to the one or the other. The 'Jesus of history' has often been called the historical Jesus while, on the other hand, the 'Jesus of faith' is known as the kerygmatic Christ. The distinction pre-Easter Jesus and post-Easter Jesus, respectively, is also used for this purpose. Consideration of the meaning of these expressions and, in particular, of the reasons for these various distinctions, may help us understand why the question as to the continued importance of Jesus is still being asked. If Jesus were to be viewed merely as a historical figure who played a particular role in ancient history, then the question about the significance of his life would be similar to the one about the significance of people like Aristotle or Plato or Alexander the Great. Nobody who knows something of world history would deny the value of the historical investigation of these figures. Jesus, like others from the ancient or less ancient past, may in my view indeed be added to such a "who is who in world history' list. Jesus is important in this regard since he is viewed as an influential factor in the course of world history. For instance, in a note on the stoning of James, the brother of Jesus, Josephus (Ant 20.9.1 - Whiston 1978:423) refers to James as 'the brother of Jesus, who was called Christ'. Here we are not dealing with a honorific, as is the case with the same words ('Jesus, who is called "Christ"') in the Gospel of Matthew $(1: 16$, see also Mt 27:17, 22). This is also the case with the Roman historian Tacitus ( $A n$ 15.44, written circa $110 \mathrm{CE}$ ) and with other 'non-Christians' (cf Whiston 
1978:639-647) who subsequent to Josephus made pejorative remarks about 'Christ' or 'Christians'5. Clearly, the reasons for the importance of Jesus to people outside the Christian believing community are different from the reasons of those who believe in him and like him. I shall in this paper indicate very briefly why the question as to the historical Jesus, seen from the vantage point of both the church and the broader community, should be asked at universities.

But this is not the only concern of this paper. The question as to the importance of Jesus is today irrevocably bound to the fact that the historical Jesus is also taken to be the kerygmatic Christ. Sometimes there is reference, in this context, to the proclaiming Jesus and the proclaimed Christ. The dialectical conceptual pairs 'historic-kerygmatic' and 'proclaimer-proclaimed' appear first in the title of a book written in 1896 by the dogmatician of Jena in the old Prussian Empire, Martin Kähler (1835-1912). There he made the distinction between the historic Jesus, real Christ ('historische Jesus, wirkliche Christus') and the 'geschichtliche', biblical, in other words, proclaimed Christ ('biblische Christus, gepredigte Christus'). These concepts do not only evince a distinction between the historisch-geschichtlich and wirklich-biblisch/gepredigt, but also between Jesus and Christ. This distinction is also related to the dialectic between the pre-Easter Jesus and the post-Easter Jesus.

Why do scholars draw these distinctions? The answer lies in the fact that Jesus did not regard himself as the Christ, as the Child of Humanity, as the Child of God, as God. Nor was he viewed or recognised as, for instance, the Child of God by the people around him. The Bible (meaning the New Testament) and later the church fathers, as well as the drafters of the fourth-century creeds, proclaimed and confessed him in these terms. It is, furthermore, not true that all these names (Christ, Child of Humanity, Lord, Child of God, God) were used overnight by all followers of Jesus with reference to Jesus. An investigation into the development of the origins of Christianity and the handing down of traditions relating to Jesus, brings to light trajectories which would indicate the succession of different historic phases.

It is therefore understandable that to be confronted for the first time with the following results from the past two hundred years of New Testament scholarship would definitely prove confusing to the uninformed person: the complicated transitions from oral to written traditions; the influence on oral and written traditions of, first, the eastern Mediterranean and, later, the Graeco-Roman cultural contexts; source interdependence, for instance, the fact that Matthew and Luke used, among others, Mark as a framework and source of information, but that each of them, nevertheless, freely diverged from it in constructing a specific, unique message; the consequences of the fact that documents originated at different dates, for instance that Paul wrote his letters before the final editing of the Gospel of Mark, and that John was to a significant degree not dependent on - as well as written after - Luke and Matthew. 
Drawing an accurate picture of Jesus from these complicated particulars is certainly no easy task. The question as to the historical Jesus is prodigiously complicated. Who is the 'real Jesus'? We must remember that we do not have immediate access to what Jesus thought of himself and of God. Jesus, like Socrates, did not himself put to paper either the message of his words and deeds or the meaning of his birth and death. It would, in any case, have been very strange if a carpenter who made yokes and doorframes, somebody probably like Jesus who was part and parcel of the peasant farming community of first-century Galilee, would have been able to read or write! I say this in spite of the tendentious report in Luke 4:16 that Jesus, in a synagogue, read from Isaiah 61 and applied it to himself. This passage is typical of the evangelist's postEaster conviction that Jesus was the Messiah of Israel. The different aspects of the influential nature of Jesus' life were handed down only after his death by those who met God on the basis of the traditions with regard to Jesus. This handing down at first occurred orally, while the first written record te be found in the New Testament only occurred twenty-five years after Jesus' death - and by somebody who never met him personally: Paul (of Tarsus)! The Gospel of Mark, which was written circa $70 \mathrm{CE}$, followed afterwards. Mark served as source for the authors of the Gospel of Luke (written circa $85 \mathrm{CE}$ ) and of the Gospel of Matthew (written circa 85-95 CE). The Gospel of John originated independent of the three synoptic gospels towards the end of the first century.

In addition, we should not forget the way in which the documents of the New Testament were produced and reproduced. Books were, before the invention of the art of book printing by Johann Gutenberg circa $1450 \mathrm{CE}$, written, copied and translated by hand (cf Funk 1991:18). These manuscripts only appeared in book form in 300 CE. The original manuscripts (the first, foundational texts) of the New Testament are no longer extant. The earliest surviving small fragments of manuscripts date from circa $125 \mathrm{CE}$. The earliest surviving large fragments of manuscripts date from circa 200 $\mathrm{CE}$, and the earliest surviving complete manuscript of a New Testament book dates from circa $300 \mathrm{CE}$. Not two of the manuscripts of the same New Testament book from before 1454 agree in all respects with one another. Numerous 'mistakes' crept in during the process of the copying and translation of manuscripts. Determining a reliable New Testament text requires a historical-comparative investigation. The agenda of such text-historical research should not be limited to those manuscripts which resulted in the New Testament. No relevant evidence may be ignored! Under the auspices of the United Bible Societies, a team of historians, engaged in research into the origins of the New Testament, exercised certain choices by way of voting, and arranged as well as published the results in four grades of greater or lesser probability. The final product was the New Testament which is read and esteemed in churches, homes and hotels by Christians and non-Christians, or ignored by many. 
The same historical-comparative methodology, with the same modus operandi of committee work and voting used in the above-mentioned compilation of the New Testament, has been used by the Jesus Seminar ${ }^{6}$ of the Westar Institute in the USA in an investigation into the historical Jesus. These types of historical decisions are guided in particular by the criterion known as 'multiple independent attestation'. By this is meant that multiple independent written evidence has greater historical probability than both singular evidence and a plurality of interdependent literary evidence. We have to take into account that material was often amended by writers to suit their intentions and narrative structures. Such material and statements which clearly exhibit the literary preference of a particular writer and the characteristics of a post-Easter ecclesiastical setting (Sitz im Leben) often serve as directives towards those Jesus traditions which cannot historically be traced back to the oral period of 30-50 CE. Such redactional material can hardly be deemed elements of the historical Jesus. This kind of historical research assumes that the followers of Jesus attributed or applied to him general 'wisdom' derived from their experience of life and the world in the same way that writers did with regard to legendary sages like Solomon and Socrates. Thus, for example, Matthew took a great deal of trouble to represent Jesus in such a way as to conform to the Greek translation of the Old Testament (the Septuagint). In this process, he in particular, made use of apocalyptic-messianic themes which derive from a shared late first-century Hellenistic-Israelite context. I have in mind especially certain Old-Testament pseudepigrapha. Luke, in turn, even though many of the traditions in his sources originated on Palestinian soil, competes in his representation of Jesus with propaganda motifs which appear in Graeco-Roman stories about deities and in the emperor cult. This latter phenomenon is related to what may be called the 'christianising' (in German: Christianisierung) of Jesus. Traces of this are already present in the New Testament and trajectories can be traced deep into the second century and even afterwards. Thus, certain statements by Jesus clearly exhibit convictions characteristic of Christians after Easter. This is related to the phenomenon that the Christian community designed certain apologetic statements, which were attributed to Jesus, in order to oppose defamatory campaigns by opponents. Careful consideration of all this information assists us in constructing a particular image of the historical Jesus which can be clearly distinguished from the images of Jesus found in the canonical and non-canonical gospels. In particular, the gospels according to Thomas and Peter, may be mentioned as being noncanonical gospels important to this investigation. The Gospel of Thomas is part of the library discovered in 1945 in Nag Hammadi, Upper Egypt. 
In this investigation, historical decisions should not be made dependent on what modern people, within the context of the Western tradition, deem to be rationally possible or acceptable. In the cultural context of people in the area of the Mediterranean in the first century, spiritual experiences led to a condition which may be called 'an altered state of consciousness' (cf Pilch 1995; Davies 1995). The particular nature of this condition is influenced by cultural associations and personality types. Without this insight from cultural psychology, rationally oriented people in a contemporary Western world would be inclined to an anachronistic understanding of the context of Jesus, and of its peculiar consciousness which involved faith healing and resurrection experiences among other things. It is therefore important to note that at present the question as to the historical Jesus is characterised by its multidisciplinary nature. Biblical Archaeology, Sociology, Cultural Anthropology, Psycho Biography, Medical Anthropology and Sociolinguistics are some of the disciplines which provide a base for the investigation of the historical Jesus.

Considering all this information, it becomes clear that we shall never be able to determine exactly what Jesus would have said or done. In addition, our attempts even to approach the core of his message cannot occur otherwise than by following a route through the literary. witness of believers who themselves started proclaiming him as Messiah, as Child of Humanity, as Lord, as Child of God, and as God. Since the time of the emperor Constantine in the fourth century CE, the church in ecclesiastical councils developed - with the help of a complicated Graeco-philosophical metaphysics and Roman legal terminology - an image of Jesus which is known as classical ontological Christology. This particular question pertaining to Jesus is primarily focused on what concerns God, and not humankind, and is therefore also known as the "Christology from above'. It is concerned with the question about the similarity in being of the personae of the Trinity. Today, apart from the distinction between an ontological (from above) and a functional (from below) perspective on Jesus, a perspective 'from the side' also appears (cf Malina \& Neyrey 1988:x-xi; Van Aarde 1994:588-591). Critical New Testament scholars are convinced that an ontological perspective on Jesus is not to be found in the New Testament, not even in Johannine literature. The functional perspective emphasises those words and deeds of the pre-Easter Jesus which gave rise to the 'majesty titles' awarded to Jesus by the earliest Christians in the post-Easter period. The perspective 'from the side' does not pose questions as to the unravelling of the interlacing of a pre-Easter and post-Easter Jesus. In this investigation the question is asked how Jesus would in all probability have been experienced by people around him, rather than how his followers interpreted his words and deeds from the perspective of a faith informed by resurrection appearances. 
Earlier, the unravelling of - and continuity/discontinuity between - the historical Jesus and the kerygmatic Christ was carried out with the assistance of a number of criteria (cf Hahn 1974:11-77; Mussner 1974:118-147; Calvert 1971-2:209-218; Du Toit 1985:281-286). The investigation went through three phases: from the Old Quest, to the No Quest/New Quest, to the Third Quest (cf Scott 1994; Telford 1994; Breytenbach 1995; Borg 1988, 1994a). The work of the Jesus Seminar focuses on the historical investigation of Jesus and the historical development of the trajectories of tradition in earliest Christianity. This project is not aimed at questions concerning the theological relevance of the historical investigation of Jesus. A number of individual researchers who form part of the Jesus Seminar (including myself) do, however, as far as their own research is concerned, investigate theological issues. The results of the historical investigation of the members of the Jesus Seminar tend towards a minimum consensus with regard to Jesus as someone from the peasant farming community of Herodian Galilee with an 'a-political' criticism of the temple and a non-apocalyptic, inclusive and anti-hierarchical vision on the Kingdom of God. These investigations indicate that Jesus communicated his vision, in particular, by means of short proverbial expressions, his dealings with deklassierten Personen (Bultmann 1965a:11) and exorcisms. His words and deeds are therefore seen as interacting with one another.

As far as my own historical investigation is concerned, its multi-disciplinary nature is typical. In this I concur with fellow historical Jesus scholars. Viewed literarily, relevant documents are read against the background of their chronological periods and respective contexts. As I mentioned earlier, a multiplicity of congruent, independent evidence from a particular tradition carries relatively greater historical weight (cf esp Crossan 1991:427-450). The influence of Easter on the handing down of Jesus traditions is taken into account for distinguishing historically between the pre-Easter and the post-Easter Jesus. Pre-Easter traditions are interpreted within 'ideal-typical' situations in terms of a first-century, eastern-Mediterranean society. My contention is that Jesus grew up as a fatherless son. This point of departure is supported by a historic-critical deciphering of a post-Easter trajectory with regard to a Joseph-figure who either, according to a tradition behind and beyond Matthew and Luke, adopted Jesus or, according to John, is Jesus' biological father. However, the figure of Joseph as Jesus' father does not occur in the early sources (Thomas, Q, Paul and Mark). This fact historically satisfies the criterion of multiple, independent attestation. To me, Jesus' fatherlessness is therefore a fact which should be taken into account when one considers the historical Jesus' identity, his a-patriarchal ethos, his behaviour towards endangered women and children, and especially his trust in God as his $A b b a$ (cf Van Aarde 1995, 
1997a, 1997b, 1997c). Literary, historical and social contexts are therefore considered in an integrative way. However, 'fatherlessness' is in this project not a topic about which one fantasises as it was done from a 'psychopathologically' viewpoint by those freisinnigen Theologen of 'Old Quest'-fame (cf Schweitzer 1966:376). Their liberal images of Jesus caused some influential theologians to become supporters of a 'No Quest'. Karl Barth, for instance, avoided the whole question of the historical Jesus by saying decisively: 'I do not know this man' (Barth, in Jüngel 1995:87).

\section{CAN WE KNOW ANYTHING OF THE HISTORICAL JESUS?}

The fact that we do not have Jesus' own words, but only those ascribed to him by other witnesses, may easily lead to two fallacies. On the one hand, this may lead us to the opinion that it would be impossible to determine a historical core for Jesus of Nazareth. On the other hand, we may judge it undesirable to undertake a historical Jesus investigation because the real Jesus would only be that Jesus of whom there is reference in the Bible, while others might add, that Jesus of whom the ecclesiastical creeds bear witness. In this regard, it is necessary to mention again the name of Martin Kähler (1896). The title of his book, to which we referred earlier, already indicates that he is of the opinion that only the Christ proclaimed ('gepredigt') in the Bible (New Testament) really matters. This view is currently found in the work of, among others, Luke Timothy Johnson $(1995,1996)$, a New Testament scholar of Emory University in Atlanta.

Concerning the view that the quest for the historical Jesus would be 'impossible', an appeal is often wrongfully made to the work of Rudolf Bultmann, the most influential New Testament scholar of the twentieth century. Prompted by Albert Schweitzer's finding ([1906] 1910) that exegetes who draft biographies of Jesus often project their own ideology with regard to ethical-religious perfection, goodness, sinlessness and holiness onto the inner being of the person Jesus (cf also Joy 1948:23; Kähler 1969:28 note 1a), Bultmann showed little enthusiasm for what he called the 'psychological fallacy'. For example, Bultmann would not, precisely in order to avoid such a fallacy, designate the baptism of Jesus (cf Mk 1:9-11) a Berufungsgeschichte (a 'call story'). Kähler (1969:14) already pointed out that such a biography of Jesus would be impossible because the available sources do not mention anything relating to such psychological dispositions ${ }^{7}$. On the other hand, as could be expected, Albert Schweitzer felt it necessary to react also to theories about a supposed mental disorder of Jesus. In his doctoral thesis, The psychiatric study of Jesus, which served as the completion of his medical examinations, Schweitzer ([1913] 1948:46-53) responded to four 'psychopathologists' who presumed on his opinion that Jesus acted within the contemporary 
framework of 'wild' apocalyptic expectations (cf Schweitzer 1948:46-53). Using the so-called psychopathological method ('which conceived its task to be the investigation of the mental aberrations of significant personalities in relation to their works' Schweitzer 1948:33) as an angle of incidence, these men depicted Jesus as someone who was suffering from hallucinations and paranoia (cf also Schweitzer 1966:376-380). Schweitzer's reaction to these 'psychopathologists' was similar to those who constructed a 'liberalized, modernized, unreal, never existing Jesus ... to harmonize with [their] own ideals of life and conduct' (Joy 1948:19):

\begin{abstract}
De Loosten, Hirsch, [Rasmussen] and Binet-Sanglé busy themselves with the psychopathology of Jesus without becoming familiar with the study of the historical life of Jesus. They are completely uncritical not only in the choice but also in the use of sources .... We know nothing about the physical appearance of Jesus or about the state of his health.
\end{abstract}

(Schweitzer 1948:44-45, 47)

Bultmann ([1926] 1988:8-10) concurs in his well-known Jesus book when he says that we know, 'psychologisch verständlich', virtually nothing of the 'life' and 'personality' of Jesus. Bultmann's student, Ernst Käsemann ([1954] 1960:212-213), also agrees ${ }^{8}$. But, according to Walter Schmithals, another student of Bultmann, in the Nachwort to Bultmann's Jesus book (Schmithals, in Bultmann 1988:149), precisely here a gross misunderstanding ('ein groteskes Mißverständnis') would arise with many people, if they were to believe that Bultmann (or, for that matter, Schweitzer) considered it impossible to carry out a historical investigation of Jesus. A little further in the same Jesus book, Bultmann (1988:13) says, in fact, that we know enough of the message of Jesus to be able to draw a coherent picture of it for ourselves ${ }^{9}$ (cf also Painter 1987:102). The problem is, in other words, not that we do not know anything of the historical Jesus, but whether what we do know about him is of any importance for faith. It was precisely this question which almost caused unpleasantness of a personal kind between Bultmann and his students, in particular Ernst Käsemann and Joachim Jeremias. Fortunately, both Käsemann ([1964] 1969:36) and Bultmann (1965b:190) declared from the beginning that the matter at hand was more important than persons ${ }^{10}$.

The question, however, remains: what is this matter which is of such importance? Can one not be a Christian without asking the question about the historical Jesus? Marcus Borg (1994b:184), a contemporary Jesus researcher, correctly points out that 
there have always been - and still are - Christians who believed in Jesus as Christ, as Child of God and as God without ever having engaged themselves in the quest for the historical Jesus! Kähler ([1896] 1969:44) already expressed the same conviction long ago when he pointed to the 'childlike faith' of millions throughout history'1. As in the case of Martin Kähler, Luke Timothy Johnson (1995:44), to refer to a recent interlocutor, is very much aware of the fact that the post-New Testament 'developed, dogmatic Christ of church doctrine (true God and true man)' is not the 'image' of Christ (or Jesus - Johnson uses the terms as equivalents) 'limned in the pages of the New Testament'. According to him the writings of Paul (and of 1 Peter and Hebrews) 'converge' with the canonical gospels and the creation of an image which was and is 'instantly graspable' by uncritical Christians, who let their lives be shaped by it and not by historiography.

In a specific response to this, John Dominic Crossan (1996a:42) points out that, in fact, there is not only one type of gospel format, namely a narrative one, as in the case of the four canonical gospels. There are also gospels in the format of a collection of proverbs of Jesus ('sayings or aphorisms gospel') which undoubtedly came into being before the narrative type. We have the latter, respectively, in the form of the Sayings Gospel Q (hidden in the Gospels of Matthew and Luke), and in the gnostically oriented Gospel of Thomas (recovered in, respectively, Greek fragments and in a Coptic translation found under the sand at Oxyrhynchus and Nag Hammadi in Egypt). Unlike the narrative gospels or the argumentative discourses of Paul in letter format, the 'sayings or aphorisms' type of gospel did not attach any redemptive meaning to the death of Jesus. What, then, is historically speaking 'true' with regard to the 'historical Jesus' in contradistinction to the 'kerygmatic Christ'? After all, the content of both these types of gospel format cannot lay claim to historicity! Even if one were to work only with the canonically accepted gospels, the problem will not be solved, since the interpretations of the death of Jesus by Mark and John differ radically, as Crossan (1996a:42-33) indicates:

For Mark, the passion of Jesus starts and ends in agony and desolation. For John, the passion of Jesus starts and ends in control and command. But I repeat, as gospel, both are equally but divergently true. Both speak, equally but divergently, to different times and places, situations and communities. Mark's Jesus speaks to a persecuted community and shows them how to die. John's Jesus speaks to a defeated community and shows them how to live.

(Crossan 1996a:44) 
Luke Timothy Johnson misses the important point. The issue is not that historical Jesus researchers want to ground their faith in historiography and not in the normative nature of Scripture! One cannot formulate it better than Crossan (1996a:45): 'our faith is not in history, but in the meaning of history; not within a museum, but within a church'. Eberhard Jüngel ([1990] 1995:88) says the same thing in different words: 'faith in Jesus as the Christ cannot be grounded in the historical Jesus, it must nevertheless have a support in him'. Jüngel (1995:83) is quite correct when he says that God cannot be known historically, but only on the basis of God's revelatory acts in respect of which the faith from the side of the one who receives the revelation corresponds. God revealed himself through the medium of historical events. By this I mean that, for believers, God manifested himself in the human Jesus of Nazareth. Schillebeeckx (1987:13) says: 'Without Jesus' historical human career the whole of Christology becomes an ideological superstructure'. Although this manifestation occurred historically, and is therefore in principle open to historical investigation, the act of faith that confesses that Jesus is the Christ, the Lord, the Child of God, God himself, is not grounded in historiography as such: "no one can say that "Jesus is the Lord" [Kúpios

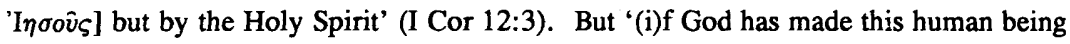
- and not just any human being - to be the Christ, as faith confesses, the faith must be interested to know what can be known about this person. But not in order to ground faith in Jesus Christ historically, but rather to guard it from docetic selfmisunderstanding' (Jüngel 1995:97).

Bultmann's (1965a:9) well-known observation, that it is the thatness ('Daß') of Jesus which is important for faith and not his whatness ('Was'), deals with precisely this type of dialectic. It is also on this point that students of Bultmann (Käsemann, Jeremias and Jüngel) misunderstood their mentor. Bultmann (1965b:191) was not of the opinion that a 'historical and material' antithesis (Käsemann 1969:36) exists between Jesus and the kerygma of the early church. Bultmann (1965a:9; 1965b:191) spoke of a distinction between 'historical continuity' and 'material relation' ('Unterschied zwischen historischer Kontinuität und sachlichem Verhältnis'). By this he meant that a continuity clearly exists between Jesus and Christ - the two names 'Jesus' and 'Christ', after all, refer to the same historical person, but there is no historical continuity between the kerygma which takes the death of Christ Jesus as a redemptive event, and the historical Jesus himself who did not call on people to believe in him, but to depend, like him, on the presence of God until death. However, there is a material relation between the message of Jesus and the ecclesiastical kerygma: both announce that life in the Kingdom of God is qualitatively and radically different to the sense which people find in cultural arrangements (cf Bultmann 1969:223-235) - life. in the Kingdom of God is life according to the Spirit and not a life according to the flesh. Paul therefore did not need to ground his kerygma in Jesus, the Jew, because then he 
would have grounded faith in the Christ who as human came from the cultural context

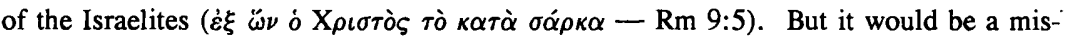
representation of Paul, as Robert Osborn (1990:221) rightly sees, when one says 'that Jesus in his flesh may well have been Jewish, but that as the resurrected Christ he certainly is not'. Indeed, to Paul, Jesus would be bound to particularism if the significance of Israel's messiah would have been solely of an ethnic nature. Such a messiah would be 'Christ according to flesh' ( $\mathrm{Rm}$ 9:5). But this is not the material essence of the traditions of Jesus which had been handed down to Paul. On the contrary, there is a material relation between Jesus of Nazareth and the Christ Jesus proclaimed by Paul. Even though he did not deem it necessary to reconstruct a historical Jesus before he could believe, Paul could only base his kerygma about the life 'in Christ' because he had knowledge of the handed-down tradition that Jesus, subversive towards the culture of his time, announced God's 'unbrokered' kingdom. The observation by Jeremias (in Käsemann 1969:24) that Bultmann runs the risk of replacing the message of Jesus with the preaching of Paul, is therefore entirely inappropriate. In Robert Funk's (1996:41) version of Jesus' understanding of the Kingdom of God nobody else but Paul's statements in particular are echoed:

God's domain was for Jesus something already present. It was also something to be celebrated because it embraces everyone - Jew, gentile, slave, free, male, female. In God's domain, circumcision, keeping kosher, and sabbath observance are extraneous. The kingdom represents an unbroken relationship to God: temple and priests are obsolete.

The gospels presented this message in a version different from that of Paul, while John presented it in a version different to that of Mark. A harmonised composition of the Christ events is not 'normative', as Luke Timothy Johnson would have it; nor is a necessarily relativistic choice of one version above another. It is the mode of the dialectic between pre-Easter and post-Easter which is normative. I thus fully concur with Crossan (1996a:45):

It is because of that normative process that each Christian generation is called both to consider the historical Jesus and simultaneously to reinterpret that figure as Christ or Lord. Each side of the dialectic must be done over and over again .... What is permanent is the dialectic. 
Seen in this way, the imposed injunction to repeat this same dialectic mode amounts to our always being oriented again by the evidence in the New Testament and other intracanonical literature - where else do we learn of God's revelation in and through Jesus of Nazareth? To the writers of the New Testament he was: Jesus as Christ, Jesus as Child of God, Jesus as Lord. And for me, I would like to add: Jesus as God, but then not necessarily in the classical ontological sense of the word alone. In other words, when Funk (1996: 304) deliberately chooses to turn his back on Paul12 and, for that matter, decisively also on Bultmann as a dialectic theologian, misnamed by Funk (1996:300ff) as 'neo-orthodoxy', one can have respect for his taking Jesus' subversiveness seriously. However, to approach the new millennium, with Jesus but without the New Testament or the church as the believing community of Christians, would not be an act of faith which neither necessarily rests on or is implied by the faith of the historical Jesus. It is true, the New Testament should not be put, as William Marxsen (1968:284) formulates it, 'in the place of Jesus as the revelation'. Nevertheless, I would concur with William Thompson, building upon the insights of Paul Ricoeur and David Tracy:

Christianity is not a religion of a book, but of a person, Jesus [as] the Risen One. But the Jesus event has left us 'traces' of itself in the New Testament, and it is chiefly to this 'text' that we must turn for 'normative codification' of the Jesus event. That we go to Jesus through the biblical text is finally rooted in our tradition-bound character. Like all other things human, Christianity is an historically-mediated religion.

(Thompson 1985:115)

\section{THE MATERIAL RELATION BETWEEN THE JESUS OF HISTORY AND THE JESUS OF FAITH}

There is, in spite of the historical discontinuity between the historical Jesus and the kerygmatic Christ, a very important material link between the message of Jesus and the preaching of the earliest Christians in the New Testament. I would like to illustrate this by means of the word $A b b a$ ('Father'). Both Jesus and Paul referred to God as 'Abba', and both were of the opinion that God could adopt people who did not biologically belong to the family of Abraham - people who could not, in other words, be taken to be 'children of God'.

According to a very early tradition ${ }^{13}$, which is confirmed by multiple independent evidence, Jesus was seen as someone who implicitly took himself to be the 'Child of God' when he called upon God as 'Abba' or 'Father'. Under the influence of Graeco- 
Roman mythology, the Roman emperor cult and the Hellenistic-Semitic wisdom tradition (cf Van Aarde 1997a), Christians added much more to the appellation 'Jesus as Child of God' than Jesus himself probably had in mind (cf Van Aarde 1997b). The fact that these additions played a role in the handing down of the relevant tradition makes no difference to the significance of the tradition that Jesus was adopted by God as 'Child of God' at his baptism by John the Baptist ${ }^{14}$. The Q tradition (Lk 3:8; Mt 3: 9) contains, in the context of the baptism of Jesus, a statement by John the Baptist which critically rejects the self-assured assumption of Israelites that they have 'Abraham as father' because 'God can raise up children for Abraham right out of these rocks'. According to Matthew (3:7), this statement was directed at the Pharisees and Sadducees. In this respect, both Jesus and John the Baptist represented the critical voice of the prophets against the royal hierarchy, and both were killed as a result.

A position which Jesus did not share with John the Baptist, was that God would only intervene at the end of time in an apocalyptic way in order to create the ideal condition of what is right and just. According to Jesus God rules here and now, and not only later ${ }^{15}$. In the words of Dominic Crossan (1996b:44-47), but with my own parenthesis concerning the relation between the baptism of Jesus by John the Baptist and the theme 'children of Abraham' in the Johannine and Pauline tradition, this difference can be articulated as follows: John the Baptist was of the opinion that God would soon intervene as an avenger. God is like a forester who will separate the good trees from the bad ones with his axe, like a farmer who separates the wheat from the chaff with his fork. In this view, there are only two ways: the good and the bad, and people have little time to decide between them. Like the prophets of old, John announces that God is going to intervene in order to correct an evil condition so oppressed people may be saved. Like other 'rebel leaders' - referred to, among others, by the Jewish historian Josephus - John sets out to the desert across the river Jordan in order to symbolically, like Moses or Joshua, lead people back to the promised land with the help of God (cf Funk 1996:188). But, unlike other apocalyptic prophets, John did not collect his followers en masse to lead them into the promised land across the Jordan. His strategy was different. Thus far Dominic Crossan, and now my parenthesis.

People - referred to by Luke (3:7) as a 'multitude' (óx $\left.\lambda o{ }^{\prime}\right)$ - who could not, in the view of the Pharisees and Sadducees, be deemed 'children of Abraham' and therefore must be labelled 'sinners' came, according to Mark (1:5), to the Baptiser from all over Judea and, in particular from Jerusalem in order to be baptised in the river Jordan because they recognised (in Greek: $\dot{\varepsilon} \xi \circ \mu о \lambda о \gamma \varepsilon \dot{\varepsilon} \sigma \alpha \iota$ ) that they belonged to the category

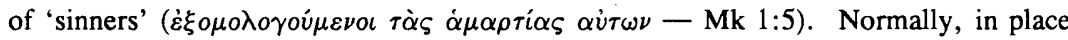
of the word 'recognise' another word is translated, namely 'confess'. To confess, 
however, presupposes the recognition that one has acted wrongly. The original Greek does not necessarily have this meaning (cf Louw and Nida 1988:419-420). According to the semantic dictionary of Louw and Nida (1988:419), this particular Greek word can mean: 'to express openly one's allegiance to a proposition or person'. Who then would be the people who would openly declare that they belong to the group labelled 'sinners'? Funk (1996:194) is, I believe, entirely correct in understanding the reference to 'sinners' in this context as 'outsiders'. But 'outsiders' regarding to what or whom? They were, according to the temple cult, 'outsiders' with regard to the house of Israel, the family of Abraham, the 'Israel of God' to whom God is the 'Father'.

One need not doubt the historicity of the baptism of Jesus by John the Baptist, but I doubt whether Jesus himself initially understood his baptism as 'apocalyptic penance' ('Bußtaufe' - Bultmann 1968:65; Jeremias 1971:49; Schmithals 1986:65; 1994:99). We have already seen that 'recognition' ( $\left.\dot{\xi} \xi \circ \mu \circ \alpha_{\circ} \gamma \varepsilon \dot{\varepsilon} \alpha \alpha\right)$ need not necessarily presuppose 'confession of guilt'. Perhaps Jesus did in the beginning share the apocalyptic expectations of John the Baptist - who knows? The little information we do have, however, indicates that Jesus' motive to come to John 'from Nazareth [in Galilee]' (Mk 1:9; cf also Mt 3:13) to be baptised, was the same as that of those who came 'from Jerusalem [in Judea]' (Mk 1:5). But I am not denying that Mark interpreted the baptism of Jesus from the perspective of a post-Easter debate about who would be 'insiders' and who 'outsiders' (cf Funk 1996:194). In additional editorial material (see Kloppenborg 1988:10-11), John the Baptist - according to Luke - expected people like publicans and soldiers who came to be baptised, to follow a particular ethical lifestyle. This lifestyle is to be distinguished from that of those labelled 'snakes, viperous brood' ( $\gamma \varepsilon \nu \nu \dot{\eta} \mu \alpha \tau \alpha \dot{\varepsilon} \chi\llcorner\delta \nu \hat{\omega} \nu$ ) by the Sayings Gospel Q (3:7). According to the Q tradition, it is such people who are called upon to produce fruit befitting conversion and not the so-called 'outsiders' who came to be baptised. This is ironic because precisely those labelled 'snakes, viperous brood', the leaders of the family of Abraham, considered themselves justified before God. Actually, according to this particular tradition in $\mathrm{Q}$, it would be useless if they were to attempt to flee the coming apocalyptic catastrophe.

The expression 'snakes, viperous brood' ( $\gamma \varepsilon \nu \nu \dot{\eta} \mu \alpha \tau \alpha \dot{\varepsilon} \chi \iota \delta \nu \hat{\omega} \nu)$ also occurs in other Q traditions (see Q 6:43-45 and 11:39-52) as words of Jesus himself. These people were, to John the Baptist ( $Q$ 3:8), those who boasted that they had 'Abraham as father'. But God is able, according to the $Q$ tradition, to 'raise up children for Abraham right out of these rocks'! Matthew (3:7) specifies quite clearly that these people are the Pharisees and Sadducees. Also, when Matthew (23:33) incorporates the relevant word 
of Jèsus in the Sayings Gospel Q (11:39-52), namely 'snakes, viperous brood', he lets Jesus refer specifically to those who sit on the 'chair of Moses'. The same conviction is found in the Gospel of John (8:31-59; see Vellanickal 1977:286-293). Multiple, independent evidence therefore confirms the historicity of the baptism of 'sinners' by John the Baptist and his criticism of the temple cult of Jerusalem.

Jesus, like the other people baptised by John the Baptist, was for various reasons probably not considered to belong to the 'people of the covenant' (see Van Aarde 1997c, 1997d). John the Baptist's message that God could in a supernatural way produce 'children of Abraham' and that their 'sin' could be forgiven by God outside the structures of the temple - undoubtedly must have touched the hearts of the 'outsiders' - how else are we to understand the tendentious denial by Josephus (Ant 18.5.2 - cf Whiston 1978:382) that the baptism by John did amount to the forgiveness of sin but that, because he attracted so many people, Herod [Antipas] feared him and had him killed (cf Jeremias 1971:4; Crossan 1994:34)?

In a different post-Easter context, against the background of a dispute with the temple authorities relating to the question of who truly are the 'children of Abraham' (in other words, the 'children of God'), the writer (or writers) of the Gospel of John (8:46) attribute to Jesus words which reveal that this debate is related to the tradition that Jesus was considered a 'sinner'. It is therefore understandable that the early church wanted to defend the 'sinlessness' of Jesus (see Hb 4:15; GNaz 2; also by implication Mt 3:14-15). 'Sinlessness' is, according to the Johannine tradition, implicitly the fruit of the life of 'God's children' (see 1 Jn 3:9). Vellanickal (1977:268) presents the ring composition of 1 John 3:9 in the following way:

A Everyone who is BEGOTTEN OF GOD

B Does NOT commit SIN

C Because His seed dwells in him

$B^{1}$ And he is NOT able to SIN

$A^{1}$ Because he is BEGOTTEN OF GOD

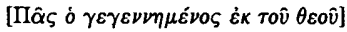
$[\dot{\alpha} \mu \alpha \rho \tau i \alpha \nu$ oỉ $\pi 0 \iota \varepsilon \hat{\imath}]$

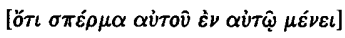

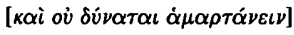

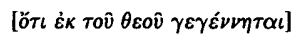

In the Gospel of John (1:18), Jesus is the pre-existent 'only begotten Son' ( $\dot{0} \mu \circ \nu 0 \gamma \varepsilon \nu \grave{\eta} \varsigma$ viós) of God ${ }^{16}$. Jesus' 'sonhood' is related, according to the Johannine vision, to the conviction that Jesus is the 'one sent by God'. Jesus also has the authority to grant everyone who believes in him the right to be called 'children of God' (Jn 1:12). They are as such 'not born of sexual union, not from physical desire, and not from male willfulness: they were born of God' (Jn 1:13). According to the Johannine tradition, 
'children of God' live a 'righteous life' and do not 'continue sinning' (1 Jn 29-3:1). God's 'children' are free from the bondage of $\sin$ (Jn 8:31-36). This last reference is to that passage in the Johannine tradition which is related to the dispute between Jesus and the Pharisees with regard to whether the 'children of Abraham', of 'children of God', presupposes a biological relationship. More or less the same conviction is found in Paul. He, similarly, hands down the tradition that Jesus 'who knew no sin' was made 'to be sin' ( 21). I do not know whether Paul had the baptism of Jesus by John the Baptist in mind here (cf Van Aarde 1995:333). What is of importance though, is that the expression

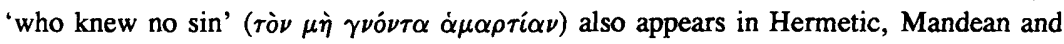
Rabbinic literature. In this literature, the expression concerns 'innocent children' who are not supposed to know what evil is (see Bultmann 1985:164-165) and who therefore have become the victims of systemic structures of $\sin ^{17}$.

With the reference above to 'children' I return to the description by Crossan of the similarities and differences between the presentist Jesus and the apocalyptic Baptiser.

When people came to him [John], he kept sending them back from the wilderness, through the Jordan, purified and forgiven into the Promised Land, there to await the imminent coming of the avenging, saving God. In essence, John was forming a giant system of purified individuals a network of ticking time bombs all over the Jewish homeland. Because of John, when Jesus began his ministry, he found already a vast network of people expectant, eager, waiting for God's power to be revealed.

(Crossan 1996b:45-47)

Crossan (1996b:47) further points out that we have quite a bit of evidence in the gospels that Jesus had an especially high opinion of John. In the Sayings Gospel Q (7:24-26) we read that Jesus refers to John not only as a prophet but as 'much more than a prophet'. Jesus also says $(Q 7: 28)$ that 'among those born of women none is greater than John; yet, the least in the kingdom of God is greater than he'. These last words confront us with a clear division between Jesus and John. Jesus did not view John as a prophetic figure only, but as being greater than the prophets. At the same time, Jesus now says that the 'least' in the kingdom of God is greater than John the Baptist. What is meant by this? It seems as if Jesus is drawing a distinction between an old dispensation of which John forms the 'apogee', and the kingdom of God which has arrived and announces a new dispensation. Jesus says that something new has 
arrived. However, it does not belong to John in the desert, but to the child in God's

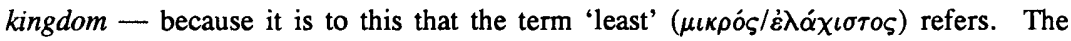
implication of this is that Jesus does not (any longer?) share the apocalyptic expectations of John. Jesus is simply not (any longer?) waiting for God's future intervention which is, sometime or another, going to bring about the dawn of a new world. One simply needs to enter the new world which God has already created here and now. 'The Kingdom is an ever-present reality in which Jesus lived and into which he invited all whom he met to enter' (Crossan 1996b:47). For Paul, this is what a life in faith amounts to. This theme, which occurs with Jesus (and in the tradition of all four canonical gospels), is also found in Paul: God adopts people as God's children (cf Van Aarde 1997e)! These 'children' do not need to have been born 'children of Abraham'! In God's 'new world' the temple cult of Jerusalem no longer determines who is to have access to God. Inclusivity and egalitarianism have become values of the gospel. 'It no longer matters whether someone is a Jew or a Greek, a slave or free, man or woman: in Christ Jesus you are all one. And, if you belong to Christ, you are also descendants of Abraham and inheritors according to the promise of God' (Gl 3:28-29).

\section{THE CONTINUED IMPORTANCE OF JESUS}

We have now reached a point at which we can pose the question about the significance of the investigation of the historical Jesus for us today. We could approach this question from a number of angles. The church, for instance, constitutes one such angle, and the university another.

As far as the church is concerned, the preaching and the creeds of the church can have no claim to be free from testing. Depending on the current scientific paradigm, criteria for testing may take different forms. Here one should bear in mind that the discourse of the church should under all circumstances be bound to the gospel of Jesus Christ. The church is supposed to be the bearer of the gospel. Therefore, it may be that people today want to test the validity of what the church says on the basis of the nature of the concrete effect of the gospel of Jesus Christ in the church and society. Be that as it may, the church inherently faces the possibility of, mostly unknowingly, falsifying and obfuscating the gospel of Jesus Christ, and even of manipulating and exploiting $(O)$ thers $^{18}$ in the name of that gospel and thus of alienating them from the gospel and the One of whom it bears witness. That possibility was already present in the case of the earliest church, as well as in the case of those who handed down orally the Jesus tradition, those who put it to paper and adapted it editorially, and those who canonised the twenty-seven documents as the New Testament. In general, we believe 
that this process - the handing down of tradition and committing to paper the Bible took place under the guidance of the Holy Spirit. However, I do not picture or experience the work of the Holy Spirit in a mechanical way. The Holy Spirit does not take away the humanity of either the writers of the Bible, or of those who, before them, had handed down the gospel, or of those who, afterwards, interpreted it. What has been included into the canon, after all, has not lost its wordly or human character. For example, one can just refer to two social phenomena which may be traced back to the patriarchal society in which the canon came into existence, and which the canon even professes, but which cannot be traced back to Jesus of Nazareth: a conception of office with a twisted claim to power and the undignified oppression of women and children.

Apart from the scientific merit of the historical Jesus investigation (because it helps us to clarify in a responsible fashion the process by means of which the New Testament was handed down), the church may with the assistance of this investigation reach greater clarity with regard to the self-understanding of Christendom. Andrie du Toit (1985:274) called this gain of the historical Jesus investigation an 'inwardly directed desirability'. But, according to Du Toit (1985:274), there is also an outwardly directed desirability. The church also needs the investigation of the historical Jesus for the sake of the interreligious debate. Passing through the world, Christians are confronted with the question: Who is this Jesus you confess and proclaim, and whom you invite us to accept as our redeemer? How is it that he, who was a particular Israelite from Galilee, is presented as universally significant? A paper character without 'flesh and blood' would, in such a situation, lack credibility! If we do not ask the question about the historical Jesus, then the kerygma and the ecclesiastical confession could become an ideology which could be manipulated as people wished. When we remind ourselves of the images of Christ presented to people of different religious persuasions during crusades, colonisation in the name of missionary work, and in gas chambers, then the historical Jesus question assists us in rediscovering the inclusive and anti-hierarchical meaning of the gospel.

Furthermore, Jesus of Nazareth ceased to be the sole property of the church a long time ago! Bogging down in the kerygmatic Christ, is, to say the least of it, hereby challenged. In a post-church situation the 'proclaimed Christ' cannot any longer claim to have priority over the 'proclaiming Jesus'. Whether we like it or not, the importance of the Jesus question stretches further than Sunday services in church buildings, further than the normative documents of the official church, further than church programmes of evangelism, further than the god-talk of Christians in the street. One need only think of novels and films, of art and music, which have Jesus as theme. One could barely imagine the implicit lack of service to a diverse community as the result of 
the unwillingness of scholars to undertake basic and fundamental research on the historic origins of Christianity and on the Jesus of history! Those in a non-Christian, post-Christian or multi-religious community, just as those in the church, could be reminded by historical Jesus research of the possibility of the alienation of the Jesus of history.

\section{CONCLUSION}

Historical Jesus research matters - at least, it contributes significantly to the historical understanding and theological application of the New Testament, because the Jesus of history is either the implicit or explicit point of departure for inquiry into the sources behind, the social locations of, and the theological tendencies represented by the New Testament writings. In the New Testament a material relation does exist between the 'proclaimer' and the 'proclaimed'. Theologians should not avoid the exegetical task to track this relation with the intention of showing the existence of a core-continuum between the Jesus of history and the Jesus of faith without, however, denying a discontinuity regarding various aspects or claiming that faith, in order to be true faith, must be based on historical facts. Historical Jesus research is fundamental to the credibility of Christianity, in that Christianity is not a 'book-religion' but represents belief patterns witnessed in the New Testament and modelled on the words and deeds of Jesus of Nazareth who is experienced and confessed by Christians as Christ and Lord, the manifestation of God.

The quest for the historical Jesus is also important with regard to the interreligious dialogue. In this realm Christianity has often, either justly or unjustly, been challenged as being exclusivistic since it is built upon the Jewishness of Jesus. But the fact is, Jesus of Nazareth, ethnically an Israelite, had been crossing boundaries all the way without being 'un-Jewish'. The kerygma about a living through faith alone finds its main support historically in a gender indifferent, ethnic unbound and cultural subversive Jesus. Therefore, with regard to engaged hermeneutics, the quest for the historical Jesus illuminates what emancipatory living, in memory of the Jesus of history, existentially entails. Being the living symbol of God's unmediated presence in terms of God's unbrokered household, the historical Jesus set and, as the risen Christ and Lord, still sets one (irrespective of gender, age, ethnicity, social and religious affilliation) free from one's distorted relationship with oneself, with others, and with God. Christian ethics is not an abstract ideology, but is based on the humaneness of the Jesus of history.

Thus, the quest for the historical Jesus is to play an important role in postmodern theological thinking. This opinion should be seen against the background of the conviction that postmodernity features a mondial and pluralistic perspective as a result of a 
broadened rationality which goes beyond both foundationalism and relativism (cf Tracy 1994:131-139). The category 'kerygmatic Christ' seems to be increasingly loosing its explanatory and heuristic power in the secular and postmodern religious age. If and when this process reaches its consummation another Christian generation will be called to reconsider the continued importance of the historical Jesus and simultaneously to reinterpret that figure as the manifestation of God.

Each side of the dialectic [between the Jesus of history and the Jesus of faith] must be done over and over again. No generation ever gets it right forever. The best we can do, and it is more than enough, is to get it adequately right for here and now. That is not personal or individual humility but structural and systemic destiny. We are doomed not by error but by time, not by mistake but by change. It is an ultimate betrayal of Jesus to think that either history or theology has him down once and for all forever. What is permanent is the dialectic.

(Crossan 1996a:45)

* This article was published in Du Toit, C W (ed), Images of Jesus, 1-37. Pretoria: University of South Africa. HTS is granted permission to reprint this article.

\section{Endnotes}

1 Jesus, son of Phabet, who was robbed of the high priesthood (Ant 6.5.3); Jesus, son of Ananus (BJ 6.5.3); Jesus, also called Jason (Ant 12.5.1); Jesus, son of Sapphias, governor of Tiberias (Vit 12.27; BJ 2.20.4); Jesus, brother of Onias, who was robbed of the high priesthood by Antiochus Epiphanes (Ant 15.3.1); Jesus, son of Gamaliel, who was proclaimed high priest (Ant 20.9.4); Jesus, the oldest priest after Ananus ( $B J$ 4.4.3); Jesus, son of Damneus, who was proclaimed high priest (Ant 20.9.1); Jesus, son of Gamala (Vit 38.41); Jesus, son of Saphat, who was the leader of a band of robbers (Vit 22; BJ 3.9.7); Jesus, son of a priest, Thebuthus (BJ 6.8.3); Jesus, son of Josedek (Ant 11.3.10).

2 Clement of Alexandria (Protr 1:1): 'We should think of Jesus Christ as we think of God'

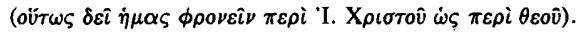

3 Ign Eph (prologue; 15:3; 18:2); Ign $R m$ (2x in prologue; 3:3); Ign Pol (8:3). What was important to Ignatius was to indicate that there is nothing self-evident in viewing God as being present in the shape of the human Jesus Christ. However, his concern is not with the conception that God, at all, appeared in the shape of a human. To people like the Greeks and the Romans of the time, such a conception was far to general for this to have been the case. What does concern Ignatius is the mystery that God appeared in the specific shape of the suffering Jesus Christ. Therefore there 


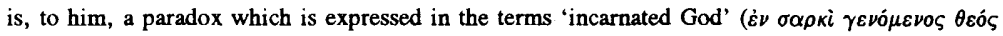

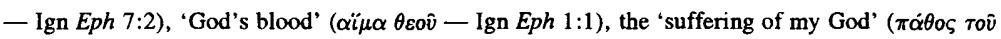

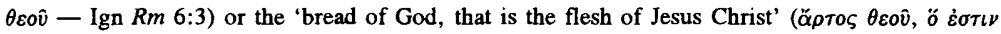
$\sigma \grave{\alpha} \rho \xi{ }^{\prime}$ I. X $\rho \iota \sigma \tau o \hat{v}-\operatorname{Ign} R m$ 7:3).

4 See also among others Bultmann (1952:248); Richardson (1979); Harris (1992). Apart from Jn 1:1, where the pre-existent Logos is called 'God', and $\mathrm{Jn} 20: 28$, where Thomas glorifies the risen Jesus with the exclamation, 'My Lord and my God', the assumption 'Christ is God' - at least on the basis of what may in all probability be said exegetically of these texts - is only made in $2 \mathrm{Th}$ 1:12, Tt 2:13 and 2 Pt 1:1. The doxology in Rm 9:5 can hardly be applied to Christ and the readings in Jn 1:18 and $1 \mathrm{Tm}$ 3:16 are, viewed text-critically, secondary (Bultmann 1968:131 note 1).

5 For information about references by non-Christians to Jesus Christ in ancient sources which may be of historical value, like those by Tacitus, Suetonius, Pliny, Celsus, Lucianus of Samosata, Thallus and Mara, son of Serapion, see Evans (1996:291-298).

6 For an explanation of the programme and aims of the Jesus Seminar, see Funk and Hoover (1997:34-37).

7 'Der sogenannte historische Jesus ist für die Wissenschaft nach dem Maßstabe moderner Biographie ein unlösbares Problem; denn die vorhandenen Quellen reichen nicht aus ...' (Kähler 1969:14).

8 'Bei einem Leben Jesu kann man schlechterdings nicht auf äußere und innere Entwicklung verzichten. Von der letzten wissen wir jedoch gar nichts, von der ersten fast gar nichts außer dem Wege, der von Galiläa nach Jerusalem, von der Predigt des nahen Gottes in den Haß des offiziellen Judentums und die Hinrichtung durch die Römer führte' (Käsemann 1960:212-213).

9 To my knowledge, the most concentrated summary of Bultmann's reconstruction of the historical Jesus is to be found in his Das Verhältnis der urchristlichen Christusbotschaft zum historischen Jesus ([1960] 1965a:11): 'Mit einiger Vorsicht also wird man über das Wirken Jesu Folgendes sagen können. Charakteristisch für ihn sind Exorzismen, der Bruch des Sabbatgebotes, die Verletzung von Reinheitsvorschriften, die Polemik gegen die jüdische Gesetzlichkeit, die Gemeinschaft mit deklassierten Personen wie Zöllnern und Dirnen, die Zuneigung zu Frauen und Kindern; auch ist zu erkennen, daß Jesus nicht wie Johannes der Täufer ein Asket war, sondern gerne $a ß$ und ein Glas Wein trank. Vielleicht darf man noch hinzufügen, daß er zur Nachfolge aufrief und eine kleine Schar von Anhängern - Männern und Frauen — um sich sammelte.'

10 'Denn ich bin mit Käsemann ganz darin einig, daß die Sache wichtiger ist als die Personen, und daß der Zusammenhalt einer Gemeinschaft, wie sie zwischen Käsemann und mir bestand und besteht, Spannungen ertragen muß, unter denen das persönliche Verhältnis nicht zu leiden braucht, Spannungen, deren Diskussion nur zur Klärung der Sache, an der uns gelegen ist, beitragen kann' (Bultmann 1965:190). 
11 'Der wirkliche, d. h. der wirksame Christus, der durch die Geschichte der Völker schreitet, mit dem die Millionen Verkehr gehalten haben in kindlichem Glauben, mit dem die grossen Glaubenszeugen ringend, nehmend, siegend und weitergegebend Verkehr gehalten haben - der wirkliche Christus ist der gepredigte Christus' (Kähler 1969:44).

12 'We can no longer rest our faith on the faith of Peter or the faith of Paul. I do not want my faith to be a secondhand faith. I am therefore fundamentally dissatisfied with versions of the faith that trace their origins only so far as the first believers; true faith, fundamental faith, must be related in some way directly to Jesus of Nazareth' (Funk 1996:304).

13 See also the Sayings Gospel Q 3:21-22 (= Mt 3:17); Mk 1:11; Jn 1:34; GHb 2 - cf Kloppenborg (1988:15-17).

14 Paul, in Rm 1:4, relates Jesus' 'adoption as Son of God' to his resurrection from death.

15 See the differences in view as expressed by the Q tradition (Lk 7:18-23 // Mt 11:2-6), and by Jesus himself (see Q 7:24-25; GTh 78:1-3) — cf Funk and Hoover (1997:301-302).

16 According to a certain manuscript, translation and patristic tradition (cf Aland et al 1994:314 note 18), although another tradition (cf Metzger 1971:198) reads the word 'God' ( $\theta \varepsilon o ́$ ) in the place of the word 'Son' (viós). Be that as it may, the 'only begotten sonhood' of Jesus is further proclaimed in $\mathrm{Jn} 3: 16,18$ and $1 \mathrm{Jn}$ 4:9.

17 Bultmann in this regard refers to Rm 8:3, which interprets the reference to Jesus' death as 'sinner' in the same way as 2 Cor 5:14, 19 and 21 (see Van Aarde 1995:333-334).

18 Using the word (O)thers I have in mind the insights of 'postmodern' philosophers like Emmanuel Levinas (cf Donoghue 1996) and Michel Foucault (cf Beukes 1996).

\section{Works Consulted}

Aland, B et al (eds) 1994. The Greek New Testament, in cooperation with the Institute for New Testament Textual Research, Münster/Westphalia. 4th ed. Stuttgart: Deutsche Bibelgesellschaft.

Beukes, C J 1966. Michel Foucault en die historisering van Anderswees. HTS 52/2 \& 3, 233-251.

Borg, M J 1988. A renaissance in Jesus Studies. Theology Today 45/3, 280-292. 1994. Jesus in contemporary scholarship. Valley Forge, Penn: Trinity Press International.

[1991] 1994a. Portraits of Jesus in contemporary North American scholarship (with Addendum), in Borg 1994:18-43. 
Borg, M J 1994b. Does the historical Jesus matter?, in Borg 1994:182-200.

Breytenbach, C 1995. Jesusforschung: 1990-1995. Neuere Gesamtdarstellungen in deutscher Sprache. Berliner Theologische Zeitschrift 12/2, 226-249.

Bultmann, R [1921] 1967. Die Geschichte der synoptischen Tradition. 7.Aufl. Göttingen: Vandenhoeck.

- [1929] 1969. The significance of the historical Jesus for the theology of Paul, in Bultmann, R, Faith and understanding, I, 220-246, ed with an introduction by $\mathrm{R}$ W Funk and tr by L P Smith. London: SCM.

- [1951] 1952. Das christologische Bekenntnis des Ökumenischen Rates, in Bultmann, R, Glauben und Verstehen: Gesammelte Aufsätze, Zweiter Band, 246261. Tübingen: Mohr.

[1958] 1968a. Theologie des Neuen Testaments. 6, durchgesehene Auflage. Tübingen: Mohr. (NTG.)

- [1960] 1965a. Das Verhältnis der urchristlichen Christusbotschaft zum historischen Jesus. 4.Aufl. Heidelberg: Carl Winter Universitätsverlag. (SHAW 3.)

- 1965b. Antwort an Ernst Käsemann, in Bultmann, R, Glauben und Verstehen: Gesammelte Aufsätze, Vierter Band, 190-198. Tübingen: Mohr.

— 1968. Das Evangelium des Johannes. 2.Aufl. Göttingen: Vandenhoeck.

- 1985. The Second Letter to the Corinthians. Minneapolis: Augsburg.

— [1926] 1988. Jesus. Neuausgabe. Tübingen: Mohr.

Calvert, D G A 1971. An examination of the criteria for distinguishing the authentic words of Jesus. NTS 18, 209-218.

Crossan, J D 1991. The historical Jesus: The life of a Mediterranean Jewish peasant. San Francisco: Harper.

— 1994. The historical Jesus: A revolutionary biography. San Francisco: Harper.

_ 1996a. Why Christians must search for the historical Jesus. Bible Review (April), 35-45.

1996b. Who is Jesus? Answers to your questions about the historical Jesus, with R G Watts. San Francisco: Harper Collins.

Davies, S L 1995. Jesus the healer: Possession, trance, and the origins of Christianity. New York: Continuum Publishing Company.

Den Heyer, C J 1996. Opnieuw: Wie is Jezus? Balans van 150 jaar onderzoek naar Jezus. Tweede druk. Meinema: Zoetermeer.

Donoghue, D 1996. Emmanuel Levinas: The philosopher of selfless love. The New York Review (March 21), 37-40. 
Du Toit, A B 1985. Die historiese Jesus en die verkondigde Christus van die evangelies, in Du Toit, A B (ed), Handleiding by die Nuwe Testament, Band IV: Die Sinoptiese Evangelies en Handelinge: Inleiding en teologie, 267-293. 2de verbeterde uitg. Pretoria: NG Kerk-boekhandel.

Evans, C A 1996. Life of Jesus research: An annotated bibliography. Rev ed. Leiden: Brill.

Funk, R W 1991. The Gospel of Mark: Red letter edition, with M H Smith. Sonoma, CA: Polebridge.

1996. Honest to Jesus: Jesus for a new millennium. San Francisco: Harper Collins. (A Polebridge Press Book.)

Funk, R W \& Hoover, R W [1993] 1997. The Five Gospels: The search for the authentic words of Jesus. Sonoma, CA: Polebridge.

Hahn, F 1974. Methodologische Überlegungen zur Rückfrage nach Jesus, in Kertelge 1974:11-77.

Harris, M J 1992. Jesus as God: The New Testament use of 'Theos' in reference to Jesus. Grand Rapids, MI: Baker Book House.

Jeremias, J 1960. Der gegenwartige Stand der Debatte um das Probleme des historischen Jesus, in Ristow, $\mathrm{H}$ and Matthiae, $\mathrm{K}$ (Hrsg), Der historische Jesus und der kerygmatische Christus, 12-25. Berlin: Evangelische Verlagsanstalt.

1971. New Testament theology, vol I: The proclamation of Jesus, tr by J Bowden. New York: SCM.

Johnson, L J 1995. The search for (the wrong) Jesus. Bible Review (December), 2044.

1996: The real Jesus: The misguided quest for the historical Jesus and the truth of the traditional gospels. San Francisco: Harper.

Joy, C R 1948. Introduction: Schweitzer's conception of Jesus, in Schweitzer, A [1913] 1948, The psychiatric study of Jesus: Exposition and criticism, tr and with an introduction by C R Joy, and a foreword by W Overholser. Boston: Beacon.

Jüngel, E [1990] 1995. The dogmatic significance of the question of the historical Jesus, in Jüngel, E, Theological essays, II, 82-119, ed with an introduction by J B Webster and tr by A Neufeldt-Fast and J B Webster. Edinburgh: T \& T Clark.

Kähler, M [1896] 1969. Der sogenannte historische Jesus und der geschichtliche, biblische Christus. Neu herausgegeben von E Wolf. 4.Aufl. München: Kaiser. (TB Band 2, Systematische Theologie.)

Käsemann, E [1954] 1960. Das Problem des historischen Jesus, in Käsemann, E, Exegetische Versuche und Besinnungen, Erster Band, 187-214. Göttingen: Vandenhoeck. 
Käsemann, E [1964] 1969. Blind alleys in the 'Jesus of history' controversy, in Käsemann, E, New Testament questions of today, 23-65, tr by W J Montague. London: SCM. (NTLi.)

Kertelge, K (Hrsg) 1974. Rückfrage nach Jesus: Zur Methodik und Bedeutung der Frage nach dem historischen Jesus. Freiburg: Herder. (QD 63.)

Kloppenborg, J S 1988. $Q$ parallels: Synopsis, critical notes \& concordance. Sonoma, CA: Polebridge.

Louw, J P \& Nida, E A 1988. Greek-English lexicon of the New Testament based on semantic domains, vol I: Introduction \& domains. New York: UBS.

Malina, B J \& Neyrey, J H 1988. Calling Jesus names: The social value of labels in Matthew. Sonoma, CA: Polebridge.

Marxsen, W 1968. Introduction to the New Testament: An approach to its problems, tr by $\mathrm{G}$ Buswell. Philadelphia: Fortress.

Metzger, B 1971. A textual commentary on the Greek New Testament. Stuttgart: UBS. Mussner, F 1974. Methodologie der Frage nach dem historischen Jesus, in Kertelge 1974:118-147.

Osborn, R T 1990. The Christian blasphemy: A non-Jewish Jesus, in Charlesworth, J $\mathrm{H}$ (ed), Jews and Christians: Exploring the past, present, and future, 211-238. New York: Crossroad.

Painter, J 1987. Theology as hermeneutics: Rudolf Bultmann's interpretation of the history of Jesus. Sheffield: Almond Press. (Historical Texts and Interpreters in Biblical Scholarship.)

Pilch, J 1995. Insights and models from medical anthropology for understanding the healing activity of the historical Jesus. HTS 51/2, 314-337.

Richardson, N 1979. Was Jesus divine? London: Epworth.

Schillebeeckx, E 1987. Jesus in our Western culture: Mysticism, ethics and politics. London: SCM.

Schmithals, W 1986. Das Evangelium nach Markus: Kapitel 1, 1-9,1. 2.Aufl. Gütersloh: Gütersloher Verlagshaus Gerd Mohn. (Ökumenischer Taschenbuch-Kommentar zum Neuen Testament 2/1.)

1988. Nachwort, in Bultmann 1988:149-158.

1994. Theologiegeschichte des Urchristentums: Eine problemgeschichtliche Darstellung. Stuttgart: Kohlhammer.

Schweitzer, A [1906] 1968. The quest of the historical Jesus: A critical study of its progress from Reimarus to Wrede, with a new introduction by $\mathrm{J}$ A Robinson and tr by W Montgomery. New York: Macmillan.

A [1913] 1948. The psychiatric study of Jesus: Exposition and criticism, tr and with an introduction by C R Joy, and a foreword by W Overholser. Boston: Beacon. 
Schweitzer, A 1966. Geschichte der Leben-Jesu-Forschung, Band 2. München: Siebenstern Taschenbuch Verlag.

Scott, B B 1994. From Reimarus to Crossan: Stages in a quest. Currents in Research: Biblical Studies 2, 253-280.

Telford, W R 1994. Major trends and interpretive issues in the study of Jesus, in Chilton, B \& Evans, C A (ed), Studying the historical Jesus: Evaluations of the state of current research, 33-74. Leiden: Brill. (NTSS.)

Thompson, W M 1985. The Jesus debate: A survey and synthesis. New York: Paulist. Tracy, D [1992] 1994. Beyond foundationalism and relativism: Hermeneutics and the new ecumenism, in Tracy, D, On naming the present: God, hermeneutics, and church, 131-139. Maryknoll, NY: Orbis.

Van Aarde, A G 1994. The epistemic status of the New Testament and the emancipatory living of the historical Jesus in engaged hermeneutics. Neotestamentica 28/2, 575-596.

- 1995. The 'third quest' for the historical Jesus where should it begin: With Jesus' relationship to the Baptiser, or with the nativity traditions? Neotestamentica 29/2, 325-356.

— [1997a]. Side-notes from Graeco-Roman and Hellenistic-Semitic literature to

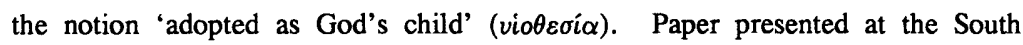
African Conference on Patristic and Byzantine Studies, University of Pretoria, August 27-29, 1997. (Forthcoming in Acta Patristica et Byzantina.)

1997b. Social identity, status envy and Jesus' Abba. Pastoral Psychology 45/6, 451-472.

[1997c]. Marriage and family: A cameo essay on Jesus' birth and childhood, in Funk, R W (ed), The acts of Jesus: What did Jesus really do? The search for the authentic deeds of Jesus. Sonoma: Polebridge. (A forthcoming publication of the Jesus Seminar.)

- [1997d]. Die Jerusalemse tempelkultus se huweliksmaatreëls versus Christelike waardes. Skrif en Kerk. (Forthcoming.)

[1997e]. Aanneming tot kind van God (viooroia) by Paulus in Romeine 8 teen die agtergrond van die Jerusalemse tempelkultus. Skrif en Kerk. (Forthcoming.)

Vellanickal, M 1977. The divine sonship of Christians in the Johannine writings. Rome: Biblical Institute Press. (AnBib 72.)

Whiston, W [1960] 1978. Josephus Complete Works, tr by W Whiston and with a foreword by W Sanford. Grand Rapids: Kregel Publications. 